\section{Deliberate self harm}

Allan House, David Owens, Lesley Patchett

\author{
Department of \\ Psychiatry, University \\ of Leeds, UK \\ A House, senior lecturer \\ D Owens, senior lecturer \\ L Patchett, information \\ officer \\ Correspondence to: \\ Dr A House, Department of \\ Psychiatry, University of \\ Leeds, 15 Hyde Terrace, \\ Leeds LS2 9LT, UK \\ email: a.o.house@leeds.ac.uk \\ Accepted 9 March 1999
}

\section{Introduction}

This paper summarises the research evidence presented in a recent issue of Effective Health Care on deliberate self harm. ${ }^{1}$

Deliberate self harm is one of the top five reasons for acute medical admissions in the UK. ${ }^{2}$ The term deliberate self harm includes intentional self poisoning or self injury (such as cutting), irrespective of the apparent purpose of the act. ${ }^{3}$

Self poisoning is the most common form of deliberate self harm. Most cases of deliberate self poisoning present to general hospitals; in the UK there are more than 150000 such attendances annually. The most common substances ingested are analgesics, particularly paracetamol and paracetamol containing compounds. ${ }^{4}$

Prevalence rates for self harm have been rising continuously since the mid-1980s to an estimated 400 per 100000 population each year. ${ }^{45}$ This incidence is higher than most others recorded in Europe. ${ }^{6}$

Effective intervention after an episode of self harm is important because these individuals are at high risk of suicide. Repetition of self harm is common, especially in the weeks immediately after an episode; and the suicide rate over the following year is 100 times greater than among the general population. ${ }^{7}$ In the year before they die, about a quarter of all suicides are seen in hospital after a non-fatal act of self harm. ${ }^{8}{ }^{9}$ Effective intervention after deliberate self harm, if it were available, could therefore be an important means of achieving the targets for reduction of the suicide rate which are outlined in the Health of the Nation ${ }^{10}$ and in the green paper, Our Healthier Nation. ${ }^{11}$

Once there were two or three times as many episodes in women as men, now there is near equality. ${ }^{2412}$ Some general hospitals now deal with more referrals of men than women. ${ }^{13}$ This trend is worth noting because the suicide rate has been increasing among young men in the past 10 years. The mean age of the self harm population is in the early 30 s for both sexes, the peak age for presentation being 15-24 years for women and 25-34 years for men. ${ }^{14}{ }^{15}$

Most people report that they take overdoses in response to social problems $\mathrm{s}^{16}$ including, difficulties with housing, unemployment, debt, illness, and conflict or loss in personal relationships. ${ }^{17}$ Evidence exists that repetition of self harm may occur despite resolution of personal problems. ${ }^{18}{ }^{19}$

After an episode of deliberate self harm, about a third of general hospital attenders may be given a psychiatric diagnosis (usually depression $^{20}$ ), and a similar proportion have had previous contact with the psychiatric services. ${ }^{21}$ About $10 \%$ are alcohol dependent. ${ }^{22-24}$ Fewer than $10 \%$ have mental illnesses such as schizophrenia or bipolar disorder. ${ }^{25}$

Box 1 shows features associated with an increased risk of repetition or eventual suicide. ${ }^{26-35}$

Risk of repetition is not uniformly distributed, and some people repeat self harm on numerous occasions. ${ }^{36}$ Although it is often assumed that those who repeat self harm frequently are predominantly women, the excess of women among chronic repeaters is probably no greater than among the self harming population as a whole. ${ }^{36}$ Little is known about multiple repeaters, except for a subgroup of women who meet criteria for borderline personality disorder, many of whom have been subject to abuse (not always sexual) in childhood. ${ }^{37}$

\section{Nature of the evidence}

The research evidence presented in Effective Health Care updates a review of the effectiveness of interventions after deliberate self harm. ${ }^{38}$ Two trials are included which were reported after the review was published. ${ }^{39}{ }^{40} \mathrm{~A}$ review of the research evidence on the characteristics of an effective clinical service for the assessment and aftercare of people who present after an episode of deliberate self harm was also undertaken. Details of the methods are reported elsewhere. ${ }^{1}$

Published findings on deliberate self harm are limited in two ways. Firstly, the data come largely from studies on general hospital attenders, although up to a third of episodes may not lead to medical contact. ${ }^{41}$ Secondly, most research has been done on deliberate self poisoning rather than other forms of self harm such as cutting. There is some overlap between these behaviours, but caution should be taken about generalising.

\section{Current services}

PSYCHOSOCIAL ASSESSMENT

Specialist psychosocial assessment (box 2) has been recommended in guidelines produced by the Department of Health and Social Security, ${ }^{42}$ the Health Advisory Service, ${ }^{43}$ and the Royal College of Psychiatrists. ${ }^{44}$

Assessment and aftercare planning may be done by staff other than psychiatrists - social workers or psychiatric nurses, for exampleproviding they have proper training and supervision. Studies have shown that the content and the quality of their assessments are comparable with those made by trainee psychiatrists. ${ }^{45-48}$ Non-medical staff take longer over assessments than psychiatrists, and recommend psychiatric follow up more often. ${ }^{48}$

Observational studies suggest that when accident and emergency (A\&E) department staff make assessments in routine clinical prac- 
Factors predicting non-fatal repetition

- A history of self harm prior to the current episode

- Psychiatric history, especially as an inpatient

- Current unemployment

- Lower social class

- Alcohol or drug related problems

- Criminal record

- Antisocial personality

- Uncooperativeness with general hospital treatment

- Hopelessness

- High suicidal intent

Factors predicting suicide

- Older age

- Men

- Previous attempts

- Psychiatric history

- Unemployment

- Poor physical health

- Living alone

Box 1 Features which predict non-fatal repetition of deliberate self harm or eventual suicide

tice, the quality of note keeping is poor, and important information such as assessment of mental state or continuing suicidal thoughts is frequently not recorded..$^{22}{ }^{49-52}$ In practice, most assessments are done by junior psychiatrists working on a rota. Standards of training and supervision are patchy, ${ }^{53}$ although it is unclear what effect this has on outcomes.

The majority of people who harm themselves arrive at hospital in the evening. ${ }^{54}$ About half have consumed alcohol and many have taken other drugs which may impair judgment. ${ }^{22}{ }^{24}$ Because it may not be possible in these circumstances to achieve accurate psychosocial assessment and arrange appropriate aftercare, it has been suggested that they should stay in hospital overnight, ${ }^{55}$ but this argument is not widely accepted. In many hospitals, more than half of attenders are discharged from the A\&E department. ${ }^{56-58} \mathrm{~Pa}-$ tients who leave hospital direct from $\mathrm{A} \& \mathrm{E}$, and especially those who leave without a psychosocial assessment, are less likely to have been offered follow up..$^{56-61}$

Only about half of hospital attenders receive a specialist psychosocial assessment before they leave, ${ }^{56}$ most are discharged as soon as they are judged physically fit. ${ }^{62} 63$ Fewer than half are offered any follow up beyond the advice that they might see their general practitioner (GP). Reports indicate that direct discharge without specialist assessment is becoming increasingly common. ${ }^{49} 56$ 64-67

There are large variations in practice between services in different regions, and also between clinical teams in the same district. $^{58616568}$ For example, there are threefold to fourfold differences in rates of discharge directly from the A\&E department, ${ }^{56}{ }^{58}$ and in rates for offering any form of psychiatric follow up.

People who harm themselves are not popular with health services staff. ${ }^{69-74}$ Similar negative
- To identify factors associated with suicidal behaviour

- To determine motivation for the act

- To identify potentially treatable mental disorder

- To assess continuing risk of suicidal behaviour

- To develop an appropriate aftercare strategy for the individual

Box 2 Aims of psychosocial assessment after deliberate self harm

attitudes are also found in the psychiatric services. ${ }^{75}$ Self harmers suffer from the stigma of psychiatric problems, and they are often seen as undeserving and detracting from the clinical care of others whose illnesses are not perceived as self inflicted. People who harm themselves repeatedly, particularly those who cut themselves, may feel especially susceptible to this problem.

\section{Aftercare}

Specialist aftercare, when it is arranged, usually involves referral to psychiatric outpatients and social services. ${ }^{76-78}$ About $5-10 \%$ of cases lead directly to psychiatric admission. In about a quarter of hospitals there is a dedicated multidisciplinary self harm team, but such teams follow up only a small minority of cases. ${ }^{56479}$ No evidence exists comparing the effectiveness of self harm teams with that of generic services.

Non-statutory agencies, particularly in larger cities, may offer help not otherwise provided to people who self harm. The best known of these agencies is the Samaritans. Early evaluations of the Samaritans produced conflicting evidence on its effectiveness. ${ }^{80} 81$ There has been no recent formal evaluation of the non-statutory agencies which offer help to self harming patients.

\section{Effective interventions}

Table 1 summarises the effectiveness of interventions to reduce the risk of repetition of deliberate self harm. The main interventions which have been evaluated in the trials are: a brief psychological treatment (problem solving therapy); more intensive but conventional psychiatric care (special clinics, outreach, continuity of therapist, routine general hospital admission, longer term contact); provision of a crisis card; intensive psychological treatment (dialectic behaviour treatment, inpatient treatment) and drug treatment (antidepressants, flupentixol).

The methodological quality of the reviewed randomised controlled trials was poor. In particular, many studies were small, and none included enough participants to give a reliable answer to the important question about the effect of intervention on repetition rates. Not all trials were analysed using an intention to treat analysis. Few used standardised measures of outcomes (such as mood or quality of life) other than repetition. The trials recruited highly selected patient groups that are not rep- 
Table 1 Summary of participants, interventions, size of trial, and proportion (\%) of participants who repeated behaviour during follow up

\begin{tabular}{|c|c|c|c|c|}
\hline \multirow[b]{2}{*}{ Study } & \multirow[b]{2}{*}{ Details of participants } & \multirow[b]{2}{*}{ Interventions } & \multicolumn{2}{|c|}{$\begin{array}{l}\text { Proportion (\%) of participants } \\
\text { who repeated behaviour during } \\
\text { follow up }\end{array}$} \\
\hline & & & Experimental & Control \\
\hline \multicolumn{5}{|l|}{$\begin{array}{l}\text { Problem solving therapy } \\
v \text { standard aftercare }\end{array}$} \\
\hline $\begin{array}{l}\text { Gibbons et al (UK, } \\
1978)^{99}\end{array}$ & $\begin{array}{l}\text { Patients }>17 \text { years who presented to } A \& E \\
\text { department after deliberate self poisoning; } \\
\text { repeaters ( } 1 \text { or more attempt) and first } \\
\text { timers; } 71 \% \text { women }\end{array}$ & $\begin{array}{l}\text { Experimental }(n=200) \text { : crisis orientated, time limited, } \\
\text { task centred social work at home (problem solving } \\
\text { intervention). Control }(n=200) \text { : routine service- } \\
54 \% \text { GP referral, } 33 \% \text { psychiatric referral, } 13 \% \\
\text { other referral }\end{array}$ & $27 / 200(13.5)$ & $29 / 200(14.5)$ \\
\hline $\begin{array}{l}\text { Hawton et al (UK, } \\
1987)^{85}\end{array}$ & $\begin{array}{l}\text { Patients }>16 \text { years admitted to general } \\
\text { hospital for self poisoning; } 31 \% \text { repeaters; } \\
66 \% \text { women }\end{array}$ & $\begin{array}{l}\text { Experimental }(n=41) \text { : outpatient problem orientated } \\
\text { therapy by non-medical clinicians. Control }(n=39) \text { : } \\
\text { GP care (for example, individual support, marital } \\
\text { therapy) after advice from clinician }\end{array}$ & $3 / 41(7.3)$ & 6/39 (15.4) \\
\hline $\begin{array}{l}\text { Salkovskis et al (UK, } \\
1990)^{100}\end{array}$ & $\begin{array}{l}\text { Patients aged } 16-65 \text { years (mean } 27.5) \\
\text { referred by duty psychiatrist after } \\
\text { antidepressant self poisoning assessed in } \\
\text { A\&E department; all repeaters with high } \\
\text { risk of further repetition; } 50 \% \text { women }\end{array}$ & $\begin{array}{l}\text { Experimental }(n=12) \text { : domiciliary cognitive behavioural } \\
\text { problem solving treatment. Control }(n=8) \text { : treatment } \\
\text { as usual (GP care) }\end{array}$ & $3 / 12(25.0)$ & $4 / 8(50.0)$ \\
\hline $\begin{array}{l}\text { McLeavey et al } \\
\quad\left(\text { Ireland, 1994) }{ }^{101}\right.\end{array}$ & $\begin{array}{l}\text { Patients aged } 15-45 \text { years (mean } 24.4 \text { ) } \\
\text { admitted to A\&E department after } \\
\text { self poisoning; } 35.6 \% \text { repeaters: } 74 \% \\
\text { women }\end{array}$ & $\begin{array}{l}\text { Experimental }(n=19) \text { : interpersonal problem solving } \\
\text { skills training. Control }(n=20) \text { : brief problem solving } \\
\text { therapy }\end{array}$ & $2 / 19(10.5)$ & $5 / 20(25.0)$ \\
\hline \multicolumn{5}{|l|}{$\begin{array}{l}\text { Intensive care plus } \\
\text { outreach } v \text { standard care }\end{array}$} \\
\hline $\begin{array}{l}\text { Chowdhury et al (UK, } \\
1973)^{102}\end{array}$ & $\begin{array}{l}\text { Patients (all repeaters) admitted to general } \\
\text { hospital after deliberate self harm; } 57 \% \\
\text { women }\end{array}$ & $\begin{array}{l}\text { Experimental }(\mathrm{n}=71) \text { : special aftercare-regular } \\
\text { outpatient appointments; patients also seen } \\
\text { without appointments; home visits to patients who } \\
\text { missed appointments; emergency } 24 \text { hour } \\
\text { telephone access. Control }(\mathrm{n}=84) \text { : normal } \\
\text { aftercare-outpatient appointment with } \\
\text { psychiatrist and/or social worker; non-attenders not } \\
\text { pursued }\end{array}$ & $17 / 71(23.9)$ & $19 / 84(22.6)$ \\
\hline Welu (USA, 1977) ${ }^{103}$ & $\begin{array}{l}\text { Suicide attempters }>16 \text { years brought to } \\
\text { A\&E department; } 60 \% \text { repeaters; } \% \\
\text { women not given }\end{array}$ & $\begin{array}{l}\text { Experimental }(\mathrm{n}=63) \text { : special outreach } \\
\text { programme-community mental health team } \\
\text { contacted patient immediately after discharge; home } \\
\text { visit arranged; weekly/twice weekly contact with } \\
\text { therapist. Control }(\mathrm{n}=57) \text { : routine care- } \\
\text { appointment for evaluation at the community mental } \\
\text { health centre next day at request of treating } \\
\text { physician }\end{array}$ & $3 / 62(4.8)$ & $9 / 57(15.8)$ \\
\hline $\begin{array}{l}\text { Hawton et al (UK, } \\
1981)^{91}\end{array}$ & $\begin{array}{l}\text { Patients aged } \geqslant 16 \text { years (mean } 25.3 \text { ) } \\
\text { admitted to general hospital after } \\
\text { deliberate self poisoning; } 32 \% \text { repeaters; } \\
70 \% \text { women }\end{array}$ & $\begin{array}{l}\text { Experimental }(n=48) \text { : domiciliary therapy (brief } \\
\text { problem orientated) as often as therapist thought } \\
\text { necessary; open telephone access to general } \\
\text { hospital service. Control }(n=48) \text { : outpatient } \\
\text { treatment once a week in outpatient clinic in general } \\
\text { hospital }\end{array}$ & $5 / 48(10.4)$ & $7 / 48(14.6)$ \\
\hline $\begin{array}{l}\text { Allard et al (Canada, } \\
\qquad 1992)^{104}\end{array}$ & $\begin{array}{l}\text { Patients seen in A\&E department for suicide } \\
\text { attempt; } 50 \% \text { repeaters; } 55 \% \text { women }\end{array}$ & $\begin{array}{l}\text { Experimental }(\mathrm{n}=76) \text { : intensive intervention-schedule } \\
\text { of visits was arranged including at least one home } \\
\text { visit; therapy provided when needed; reminders } \\
\text { (telephone or written) and home visits made if } \\
\text { appointments missed. Control }(\mathrm{n}=74) \text { : treatment by } \\
\text { another staff team in the same hospital }\end{array}$ & $22 / 63(34.9)$ & $19 / 63(30.2)$ \\
\hline $\begin{array}{l}\text { Van Heeringen et al } \\
\quad(\text { Belgium, 1995) }\end{array}$ & $\begin{array}{l}\text { Patients aged } \geqslant 15 \text { years treated in } A \& E \\
\text { department after suicide attempt; } 30 \% \\
\text { repeaters; } 43 \% \text { women }\end{array}$ & $\begin{array}{l}\text { Experimental }(\mathrm{n}=258) \text { : special care-home visits by } \\
\text { nurse to patients who did not keep outpatient } \\
\text { appointments, reasons for not attending discussed } \\
\text { and patient encouraged to attend. Control }(\mathrm{n}=258) \text { : } \\
\text { outpatient appointments only; non-compliant } \\
\text { patients not visited }\end{array}$ & $21 / 196(10.7)$ & $34 / 195(17.4)$ \\
\hline $\begin{array}{l}\text { Van der Sande et al } \\
\text { (Netherlands, } \\
\text { 1997) }\end{array}$ & $\begin{array}{l}\text { Patients aged } \geqslant 16 \text { years (mean } 36.3 \text { ) } \\
\text { admitted to hospital after suicide attempt; } \\
73 \% \text { repeaters; } 66 \% \text { women }\end{array}$ & $\begin{array}{l}\text { Experimental }(n=140) \text { : brief psychiatric unit admission, } \\
\text { encouraging patients to contact unit on discharge; } \\
\text { outpatient therapy plus } 24 \text { hour emergency access to } \\
\text { unit. Control }(n=134) \text { : usual care- }-25 \% \text { admitted to } \\
\text { hospital, } 65 \% \text { outpatient referral }\end{array}$ & $24 / 140(17.1)$ & $20 / 134(14.9)$ \\
\hline \multicolumn{5}{|l|}{$\begin{array}{l}\text { Emergency card } v \\
\text { standard aftercare }\end{array}$} \\
\hline $\begin{array}{l}\text { Morgan et al (UK, } \\
1993)^{82}\end{array}$ & $\begin{array}{l}\text { Mean age } 30 \text { years; patients admitted after } \\
\text { first episode of deliberate self harm; \% } \\
\text { women not given }\end{array}$ & $\begin{array}{l}\text { Experimental }(\mathrm{n}=101) \text { : standard care plus green card } \\
\text { (emergency card indicating that doctor was available } \\
\text { and how to contact them). Control }(\mathrm{n}=111) \text { : } \\
\text { standard care-for example, referral back to } \\
\text { primary healthcare team, psychiatric inpatient } \\
\text { admission }\end{array}$ & $5 / 101(5.0)$ & $12 / 111(10.8)$ \\
\hline $\begin{array}{l}\text { Cotgrove et al (UK, } \\
1995)^{106}\end{array}$ & $\begin{array}{l}\text { Patients aged } 12.2-16.7 \text { years (mean } 14.9 \text { ) } \\
\text { admitted after deliberate self harm; \% } \\
\text { repeaters not given; } 85 \% \text { girls }\end{array}$ & $\begin{array}{l}\text { Experimental }(n=47) \text { : standard care plus green card } \\
\text { (emergency card) green card acted as passport to } \\
\text { readmission into paediatric ward in local hospital. } \\
\text { Control }(n=58) \text { : standard follow up treatment from } \\
\text { clinic or child psychiatry department }\end{array}$ & $3 / 47(6.4)$ & $7 / 58(12.1)$ \\
\hline \multicolumn{5}{|l|}{$\begin{array}{l}\text { Dialectical behaviour } \\
\text { therapy } v \text { standard } \\
\text { aftercare }\end{array}$} \\
\hline $\begin{array}{l}\text { Linenan et al (USA. } \\
1991)^{107}\end{array}$ & $\begin{array}{l}\text { Patients aged } 18-45 \text { years who had self } \\
\text { harmed within } 8 \text { weeks before entering } \\
\text { study; all women; all multiple repeaters of } \\
\text { self harm }\end{array}$ & $\begin{array}{l}\text { Experimental }(n=32) \text { : dialectical behaviour therapy } \\
\text { (individual and group work) for } 1 \text { year; telephone } \\
\text { access to therapist. Control }(n=31): \text { months } \\
\text { treatment as usual: } 73 \% \text { individual psychotherapy }\end{array}$ & $5 / 19(26.3)$ & $12 / 20(60.0)$ \\
\hline
\end{tabular}




\begin{tabular}{|c|c|c|c|c|}
\hline \multirow[b]{2}{*}{ Study } & \multirow[b]{2}{*}{ Details of participants } & \multirow[b]{2}{*}{ Interventions } & \multicolumn{2}{|c|}{$\begin{array}{l}\text { Proportion (\%) of participants } \\
\text { who repeated behaviour during } \\
\text { follow up }\end{array}$} \\
\hline & & & Experimental & Control \\
\hline \multicolumn{5}{|l|}{$\begin{array}{l}\text { Inpatient behaviour } \\
\text { therapy } v \text { inpatient insight } \\
\text { orientated therapy }\end{array}$} \\
\hline $\begin{array}{l}\text { Liberman and } \\
\text { Eckman (USA, } \\
1981)^{108}\end{array}$ & $\begin{array}{l}\text { Patients aged } 18-47 \text { years (mean } 29.7 \text { ) all } \\
\text { repeaters; patients referred by psychiatric } \\
\text { emergency service or hospital A\&E } \\
\text { department after deliberate self harm; } \\
67 \% \text { women }\end{array}$ & $\begin{array}{l}\text { Experimental }(\mathrm{n}=12) \text { : inpatient treatment with behaviour } \\
\text { therapy. Control }(\mathrm{n}=12) \text { : inpatient treatment with } \\
\text { insight orientated therapy; both groups received } \\
\text { individual and group therapy plus aftercare at } \\
\text { community mental health centre or with private } \\
\text { therapist }\end{array}$ & $2 / 12(16.7)$ & $3 / 12(25.0)$ \\
\hline \multicolumn{5}{|l|}{$\begin{array}{l}\text { Same therapist (continuity } \\
\text { at care) } v \text { different } \\
\text { therapist (change of care) }\end{array}$} \\
\hline $\begin{array}{l}\text { Torhorst et al } \\
\quad(\text { Germany, 1987) }\end{array}$ & $\begin{array}{l}\text { Patients referred to toxicological department } \\
\text { of Technical University Munich after } \\
\text { deliberate self poisoning; } 48 \% \text { repeaters; } \\
62 \% \text { women }\end{array}$ & $\begin{array}{l}\text { Experimental }(n=68) \text { : continuity of care-therapy with } \\
\text { same therapist who assessed patient in hospital after } \\
\text { attempt. Control }(n=73) \text { : change months of } \\
\text { care-therapy with different therapist than seen at } \\
\text { hospital assessment }\end{array}$ & $12 / 68(17.6)$ & $4 / 73(5.5)$ \\
\hline \multicolumn{5}{|l|}{$\begin{array}{l}\text { General hospital } \\
\text { admission } v \text { discharge }\end{array}$} \\
\hline $\begin{array}{l}\text { Waterhouse and Platt } \\
(\text { UK, 1990) })^{110}\end{array}$ & $\begin{array}{l}\text { Patients aged } \geqslant 16 \text { years (mean } 30.3 \text { ) } \\
\text { admitted to A\&E department for } \\
\text { deliberate self harm; } 36 \% \text { repeaters; } 63 \% \\
\text { women }\end{array}$ & $\begin{array}{l}\text { Experimental }(\mathrm{n}=38) \text { : general hospital admission. } \\
\text { Control }(\mathrm{n}=39) \text { discharge from hospital. On } \\
\text { discharge both groups advised to contact GP if they } \\
\text { needed further help }\end{array}$ & $3 / 38(7.9)$ & $4 / 39(10.3)$ \\
\hline \multicolumn{5}{|l|}{ Flupenthixol $v$ placebo } \\
\hline $\begin{array}{l}\text { Montgomery et al } \\
(\mathrm{UK}, \quad 1979)^{111}\end{array}$ & $\begin{array}{l}\text { Patients aged } 18-68 \text { years (mean } 35.3 \text { ) } \\
\text { admitted after suicidal act; all repeaters; } \\
70 \% \text { women }\end{array}$ & $\begin{array}{l}\text { Experimental }(n=18): 20 \mathrm{mg} \text { intramuscular flupentixol } \\
\text { deconate for } 6 \text { months. Control }(n=19) \text { : placebo for } \\
6 \text { months }\end{array}$ & $3 / 14(21.4)$ & $12 / 16(75.0)$ \\
\hline \multicolumn{5}{|l|}{ Antidepressants $v$ placebo } \\
\hline $\begin{array}{l}\text { Hirsch et al (UK, } \\
1982)^{112} \text { R Draper, } \\
\text { S Hirsch (personal } \\
\text { communication) }\end{array}$ & $\begin{array}{l}\text { Patients aged } 16-65 \text { years admitted after } \\
\text { deliberate self poisoning; \% repeaters and } \\
\% \text { women not given }\end{array}$ & $\begin{array}{l}\text { Experimental }(\mathrm{n}=76) \text { : antidepressants-either } \\
30-60 \mathrm{mg} \text { mianserin for } 6 \text { weeks or } 75-150 \mathrm{mg} \\
\text { nomifensine for } 6 \text { weeks. Control }(\mathrm{n}=38) \text { : placebo } \\
\text { for } 6 \text { weeks }\end{array}$ & $16 / 76(21.1)$ & $5 / 38(13.2)$ \\
\hline $\begin{array}{l}\text { Montgomery et al } \\
\quad(\mathrm{UK}, 1983)^{113}\end{array}$ & $\begin{array}{l}\text { Patients with personality disorders (mean } \\
\text { age } 35.7 \text { years) admitted to medical ward } \\
\text { after deliberate self harm; all repeaters; } \\
66 \% \text { women }\end{array}$ & $\begin{array}{l}\text { Experimental }(n=17) \text { : mianserin } 30 \mathrm{mg} \text { for } 6 \text { months. } \\
\text { Control }(n=21) \text { : placebo }\end{array}$ & $8 / 17(47.1)$ & $12 / 21(57.1)$ \\
\hline $\begin{array}{l}\text { Verkes et al } \\
\quad \text { (Netherlands } \\
1998)^{39}\end{array}$ & $\begin{array}{l}\text { Adults referred after self poisoning which } \\
\text { was not their lifetime first, who did not } \\
\text { have major depression. Analysed } \\
\text { according to number of previous } \\
\text { episodes. }\end{array}$ & $\begin{array}{l}\text { Experimental }(n=46) \text { paroxetine } 40 \mathrm{mg} / \text { day, control } \\
(\mathrm{n}=45) \text { placebo for } 12 \text { months. }\end{array}$ & $\begin{array}{l}15 / 46(33) \text { if } \\
<5 \text { previous } \\
\text { attempts } \\
\text { for both } \\
\text { groups }\end{array}$ & $21 / 45(47)$ \\
\hline \multicolumn{5}{|l|}{$\begin{array}{l}\text { Long term therapy } v \\
\text { short term therapy }\end{array}$} \\
\hline $\begin{array}{l}\text { Torhorst et al } \\
\quad(\text { Germany, 1988) }\end{array}$ & $\begin{array}{l}\text { All patients repeaters who had deliberately } \\
\text { self poisoned; \% women not given }\end{array}$ & $\begin{array}{l}\text { Experimental }(n=40) \text { : long term therapy-one therapy } \\
\text { session a month for } 12 \text { months. Control }(n=40) \text { : } \\
\text { short term therapy }-12 \text { weekly therapy months } \\
\text { sessions for } 3 \text { months; all participants had brief crisis } \\
\text { intervention ( } 3 \text { days) in hospital }\end{array}$ & $9 / 40(22.5)$ & $9 / 40(22.5)$ \\
\hline \multicolumn{5}{|c|}{ Family therapy $v$ standard care } \\
\hline $\begin{array}{l}\text { Harrington et al, (UK, } \\
1998)^{40}\end{array}$ & $\begin{array}{l}\text { All children aged } \leqslant 16 \text { years, admitted to a } \\
\text { paediatric ward after deliberate self } \\
\text { poisoning, and referred for psychiatric } \\
\text { assessment. } 90 \% \text { girls }\end{array}$ & $\begin{array}{l}\text { Experimental }(n=85) 5 \text { sessions home based family } \\
\text { therapy. Control }(n=77) \text { received treatment as usual } \\
\text { in child psychiatry clinic, averaging } 3.6 \text { sessions }\end{array}$ & $11 / 74(15)$ & $11 / 75(15)$ \\
\hline
\end{tabular}

resentative of the self harm population, and their results cannot be readily generalised to routine clinical practice.

Because of small sample sizes, no trial produced a statistically significant difference in repetition rates; however, three types of intervention showed a trend in this direction. These were provision of a crisis card, problem solving therapy, and more intensive (dialectic) behaviour therapy.

PROVISION OF A CRISIS CARD

The crisis card carries advice about seeking help in the event of future suicidal feelings. A card assessed in a study in Bristol enabled the holder to speak to a psychiatrist at short notice and to request psychiatric admission in a crisis. $^{82}$ Although the majority did not avail themselves of this, there was a suggestion of reduced repetition. The card was given only to patients for whom it was their first episode of self harm.

An attempted replication (not yet published) has produced a negative result, however, perhaps because repeaters were also included in the intervention, or because psychiatric admission was not offered in the second study. ${ }^{83}$ From a clinical perspective, it is reasonable to expect that people who attend hospital after an episode of self harm should be given advice about local services which could be used in a crisis or when self harm is contemplated. But because the best mode of delivering this advice (or its likely benefits) is unknown, further research is needed.

\section{PROBLEM SOLVING THERAPY}

Problem solving therapy is a brief treatment aimed at helping the patient to acquire basic problem solving skills, by taking him through a 
series of steps: identification of personal problems; constructing a problem list which clarifies and prioritises them; reviewing possible solutions for a target problem; implementing the chosen solution; reappraising the problem; reiterating the process; and training in problem solving skills for the future. ${ }^{84}$ This usually involves about six sessions lasting one hour, with some reading materials and work to be undertaken between sessions. It can be delivered by any experienced mental health professional with suitable training and supervision. Standardisation can also be improved by using a treatment manual.

Problem solving therapy has been shown to be an effective treatment for depression in other settings, ${ }^{84}$ and in self harm studies it has led to improvement in other relevant outcomes such as mood and social adjustment. ${ }^{13}$ It may therefore be suitable for some individuals, although the scope of its applicability is unclear from the exisiting evidence.

\section{DIALECTIC BEHAVIOUR THERAPY}

This treatment was introduced as a method of helping those who engage in chronic repetitive self harm, particularly when they have associated borderline personality characteristics. ${ }^{37}$ It is intensive, involving in its full form a year of individual treatment, group sessions, social skills training, and access to crisis contact. The interest it has provoked is due to the suggestion that it leads to a reduction in self harming behaviour in a group of people for whom the services have little or nothing else to offer. Because it is an intensive intervention, better evidence of its applicability and cost effectiveness is required. It does offer, however, an interesting model for the care of people who have problems which are among the most intractable in psychiatry.

SERVICES IN THE GENERAL HOSPITAL

Even when aftercare is arranged, it is not always taken up. According to the type of service reported, $30-70 \%$ of those offered psychiatric follow up either do not attend at all or drop out after their first appointment. ${ }^{85-89}$ This is true even when the referral is to a specialist service such as an alcohol and addictions service, or when the clinic is arranged in the A\&E department so that the patient is returning to the place (perhaps to see the same person) where the original assessment was undertaken..$^{90}$

The best rates of contact are achieved by outreach programmes, ${ }^{91}{ }^{92}$ which are the only means of maintaining contact with the $20-30 \%$ of patients who will not attend clinic appointments.

Aftercare through the usual psychiatric services is unsatisfactory because repetition of self harm tends to occur early; of those who repeat within a year, a quarter will do so within three weeks. ${ }^{86}$ Few routine clinics can offer new appointments within this timescale, particularly for the numbers of people for whom it would be required.
GPS AND DELIBERATE SELF HARM

Around $50-60 \%$ of patients visit their GP in the month before an episode of self harm. ${ }^{21} 9394$ For this reason, attention has turned to the possibility of basing primary or secondary prevention in general practice. However, up to half of GP consultations before a self harm episode are not for overtly psychosocial reasons, ${ }^{95}$ so the opportunities for detection and primary intervention at this contact may not be as great as is sometimes supposed.

The most frequent management decision made after assessment is that the patient should return to see their GP. Around half of patients do visit their GP in the one to two months after an episode. ${ }^{93} 96-98$ As noted above, even when specialist aftercare is proposed, there are difficulties in arranging predictable follow up with psychiatric services. This raises the question of the role of the GP in the management of self harm. In a trial assessing intervention in primary care, nearly half of those scheduled to receive GP counselling had not seen their GP within two months of the original episode. ${ }^{85}$ These figures show that any intervention in general practice would need to have a component aimed at achieving higher attendance rates than are achieved through routine practice. There is no research evidence which answers the question of what intervention should be offered by GPs.

No detailed UK data exist about the costs of providing self harm services, and none of the trials reviewed above included a cost effectiveness analysis.

\section{Implications for practice}

All hospital attendance after deliberate self harm should lead to a specialist psychosocial assessment. This should identify motives for the act, and those associated problems which are potentially amenable to intervention such as psychological or social problems, mental disorder, and alcohol and substance misuse.

Direct discharge from A\&E should only be contemplated if a psychosocial assessment and aftercare plan can be arranged before discharge. Aftercare arrangements should include advice on the services available. Accessible and comprehensive services need to include a mechanism for engaging people who do not attend routine clinic appointments. Access to follow up needs to be rapid as repetition can occur soon after the episode. Service providers should work to improve attitudes towards self harming patients, for example through training aimed at increasing knowledge.

GPs should have ready access to training and advice about the assessment and management of self harm patients in primary care.

\section{Implications for research}

Research is needed to determine the effect of discharge directly from the A\&E department after presentation with deliberate self harm; whether it reduces the quality or outcomes of psychosocial assessment, the effect it has on subsequent contact with services, and on outcomes. 
Research is needed to establish the clinical and cost effectiveness of potential interventions. Trials should be large enough to determine whether the intervention reduces repetition, but should examine other relevant outcomes including use of health and social services, quality of life, mood, interpersonal problems, and social functioning.

Trials might focus on specific subgroups, such as chronic repeaters or those suffering from alcohol dependence, if large enough sample sizes can be recruited. Alternatively, if the subjects are to be representative of all self harm patients, they should include all hospital attenders not only patients recruited from psychiatric services or patients who visit their GP.

Research is needed into forms of self harm other than drug overdose, and in particular into cutting-its causes, outcomes, and effective treatments.

1 NHS Centre for Reviews and Dissemination. Deliberate self-harm. Effective Health Care 1998;4.

2 Hawton K, Fagg J. Trends in deliberate self poisoning and self injury in Oxford 1976-90. BMF 1992;304:1409-11.

3 Hawton K, Catalan J. Attempted suicide: a practical guide to its nature and management. Oxford: Oxford University press, 1987.

4 Hawton K, Fagg J, Simkin S, et al. Trends in deliberate selfharm in Oxford, 1985-1995: implications for clinical services and the prevention of suicide. Br $\mathcal{F}$ Psychiatry 1997;171:556-60.

5 Hawton K, Fagg J, Simkin S, et al. Deliberate self-harm in Oxford 1996. Oxford: Department of Psychiatry, Oxford Oxford 1996. Oxf

6 Schmidtke A, Bille-Brahe U, DeLeo D, et al. Attempted suicide in Europe: rates, trends and sociodemographic characteristics of suicide attempters during the period 1989-1992. Results of the WHO/EURO Multicentre Study on Parasuicide. Acta Psychiatr Scand 1996;93:32738.

7 Greer S, Bagley C. Effect of psychiatric intervention in attempted suicide: a controlled study. BMf 1971;1:310-2

8 Foster T, Gillespie K, McClelland R. Mental disorder and suicide in Northern Ireland. Br F Pyschiatry 1997;170:44752.

9 Owens D, House A. General hospital services for deliberate self-harm. F R Coll Royal Physicians Lond 1994;28:370-1.

10 National Health Service Management Executive. Health of the nation key area handbook: mental illness. London: the nation key

11 Department of Health. Our healthier nation: a contract for health. London: DoH, 1998.

12 McLoone P, Crombie I. Hospitalisation for deliberate self-poisoning in Scotland from 1981 to 1993: trends in rates and types of drugs used. Br f Psychiatry 1996;169:815 .

13 House A, Owens D, Storer D. Psycho-social intervention following attempted suicide: Is there a case for better services? International Review of Psychiatry 1992;4:15-22.

14 Charlton J, Kelly S, Dunnell K, et al. Trends in suicide deaths in England and Wales. Population Trends 1992;69: $10-6$.

15 Charlton J, Kelly S, Dunnell K, et al. Suicide deaths in England and Wales: trends in factors associated with suicide deaths. Population Trends 1993;71:34-42.

16 Bancroft J, Skrimshire A, Casson J, et al. People who deliberately poison or injure themselves: their problems and their contacts with helping agencies. Psychol Med 1977;7: 289-303.

17 Platt S, Kreitman N. Long term trends in parasuicide and unemployment in Edinburgh, 1968-87. Soc Psychiatry Psyunemployment in Edinburgh, 1968

18 Sakinofsky I, Roberts R. Why parasuicides repeat despite problem resolution. Br $\mathcal{F}$ Psychiatry 1990;156:399-405.

19 Sakinofsky I, Roberts R, Brown Y, et al. Problem resolution and repetition of parasuicide. A prospective study. Br f Psychiatry 1990;156:395-9.

20 Newson-Smith J, Hirsch S. Psychiatric symptoms in self poisoning patients. Psychol Med 1979;9:493-500

21 Morgan HG, Burns CC, Pocock H, et al. Deliberate self-harm: clinical and socio-economic characteristics of 368 patients. Br F Psychiatry 1975;127:564-74.

22 Merrill J, Milner G, Owens J, et al. Alcohol and attempted suicide. British fournal of Addiction 1992;87:83-9.

23 Suokas J, Lonnqvist J. Suicide attempts in which alcohol is involved: a special group in general hospital emergency rooms. Acta Psychiatr Scand 1995;91:36-40.

24 Wylie K, House A, Storer D, et al. Deliberate self-harm and substance dependence: The management of patients seen in the general hospital. fournal of Mental Health Administrain the general hospita.

25 Urwin P, Gibbons J. Psychiatric diagnosis in self-poisoning patients. Psychol Med 1975;9:501-7.
26 Bancroft J, Marsack P. The repetitiveness of self-poisoning and self-injury. Br 7 Psychiatry 1977;131:394-9.

27 Beck AT, Schuyler D, Herman J. Development of suicidal intent scales. In: Beck AT, Resnick H, Lettieri D, editors. The prediction of suicide. Bowie, MD: Charles Press, 1974.

28 Beck AT, Steer R, Kovacs M, et al. Hopelessness and eventual suicide: a 10-year prospective study of patients hospitalized with suicidal ideation. Am f Psychiatry 1985;142: 559-63.

29 Beck A, Steer R. Clinical predictors of eventual suicide: a 5to 10 -year prospective study of suicide attempters. $\mathcal{F}$ Affect to 10 -year prospective
Disord $1989 ; 17: 203-9$.

30 Buglass D, Horton J. The repetition of parasuicide: a comparison of three cohorts. Br F Psychiatry 1974;125:168-74.

31 Ekeberg O, Ellingsen O, Jacobsen D. Suicide and other causes of death in a five-year follow-up of patients treated for self-poisoning in Oslo. Acta Psychiatr Scand 1991;83: 432-7.

32 Hawton K, Fagg J. Suicide, and other causes of death, following attempted suicide. Br F Psychiatry 1988;152:35966.

33 Morgan H, Barton J, Pottle S, et al. Deliberate self-harm: a follow-up study of 279 patients. Br F Psychiatry 1976;128: 361-8.

34 Owens D, Dennis M, Read S, et al. Outcome of deliberate self-poisoning. An examination of risk factors for repetition. Br F Psychiatry 1994;165:797-801.

35 Wilkinson G, Smeeton N. The repetition of parasuicide in Edinburgh 1980-1981. Soc Psychiatry 1987;22:14-9.

36 Kreitman N, Casey P. Repetition of parasuicide: an epidemiological and clinical study. Br f Psychiatry 1988; 153:792-800

37 Linehan M. Cognitive-behavioural treatment of borderline personality disorder. New York: Guilford, 1993.

38 Hawton K, Arensman E, Townsend E, et al. Deliberate self harm: systematic review of efficacy of psychosocial and pharmacological treatments in preventing repetition. $B M F$ 1998;317:441-7.

39 Verkes R, van der Mast R, Hengeveld M, et al. Reduction by paroxetine of suicidal behaviour in patints with repeated suicide attempts but not major depression. Am f Psychiatry 1998;155:543-7.

40 Harrington R, Kerfoot M, Dyer E, et al. Randomized trial of a home-based family intervention for children who have deliberately poisoned themselves. F Am Acad Child Adolesc Psychiatry 1998;37:512-8.

41 Kennedy P, Kreitman N. An epidemiological survey of parasuicide ("attemted suicide") in general practice. Br f Psychiatry 1973;123:23-34

42 Department of Health and Social Security. The management of deliberate self-harm. London: Department of Health and Social Security, 1984

43 NHS Health Advisory Service. Suicide prevention: the challenge confronted. A manual of guidance for the purchasers and providers of mental health care. London: HMSO, 1994.

44 Royal College of Psychiatrists. The general hospital management of adult deliberate self-harm. London: Gaskell, 1994.

45 Gardner R, Hanka R, Roberts S, et al. Psychological and social evaluation in cases of deliberate self-poisoning seen in an accident department. BMF Clin Res Ed 1982;284: in an acc.

46 Catalan J, Marsack P, Hawton KE, et al. Comparison of doctors and nurses in the assessment of deliberate self-poisoning patients. Psychol Med 1980;10:483-91.

47 Newson-Smith JGB, Hirsch SR. A comparison of social workers and psychiatrists in evaluating parasuicide. $\mathrm{Br} \mathcal{F}$ Psychiatry 1979;134:335-42.

48 Newson-Smith J. The use of social workers as alternatives to psychiatrists in evaluating parasuicide. In: Farmer R, Hirsch S, editors. The suicide syndrome. London: Croome Helm, 1988

49 Black D, Creed F. Assessment of self-poisoning patients by psychiatrists and junior medical staff. $f R$ Soc Med 1988;81:97-9.

50 O'Dwyer FG, D'Alton A, Pearce JB. Adolescent self harm patients: audit of assessment in an accident and emergency department. BMF 1991;303:629-30.

51 Ebbage J, Farr C, Skinner DV, et al. The psychosocial assessment of patients discharged from accident and emergency departments after deliberate self-poisoning. $\mathcal{F} R$ Soc Med 1994;87:515-6.

52 Shepherd RM, Dent TH, Alexander GJ, et al. Prevalence of alcohol histories in medical and nursing notes of patients admitted with self poisoning. BMF 1995;311:847.

53 Taylor S. Training and supervision of deliberate self-harm assessments. Psychiatr Bull 1998;22:510-2.

54 Owens $\mathrm{D}$. The role of the accident and emergency department in the admission of deliberate self-poisoning patients [MD thesis]. Leeds: University of Leeds, 1990.

55 Kreitman N. Services for parasuicide and the place of poisoning within. In: Farmer R, Hirsch S, editors. The suicide syndrome. London: Croome Helm, 1988.

56 Kapur N, House A, Creed F, et al. Management of deliberate self poisoning in adults in four teaching hospitals: descriptive study. BMF 1998;316:831-2.

57 Termansen PE, Bywater C. SAFER: a follow-up service for attempted suicide in Vancouver. Can Psychiatr Assoc $\mathcal{F}$ 1975;20:29-34.

58 Thomas SH, Bevan L, Bhattacharyya S, et al. Presentation of poisoned patients to accident and emergency departments in the north of England. Hum Exp Toxicol 1996;15:466-70. 
59 Owens D, Dennis M, Jones S, et al. Self-poisoning patients discharged from accident and emergency: risk factors and
outcome. $7 R$ Coll Physicians Lond 1991;25:218-22.

60 Suokas J, Lonnqvist J. Selection of patients who attempted suicide for psychiatric consultation. Acta Psychiatr Scand 1991;83:179-82.

61 Gunnell D, Brooks J, Peters T. Epidemiology and patterns of hospital use after parasuicide in the south west of England. f Epidemiol Community Health 1996;50:24-9.

62 Ryan J, Clemmett S, Perez-Avila C. Managing patients with deliberate self harm admitted to an accident and emergency observation ward. 7 Accid Emerg Med 1996;13:31-3.

63 Ryan J, Rushdy A, Perez-Avila C, et al. Suicide rate following attendance at an accident and emergency department with deliberate self harm. F Accid Emerg Med 1996;13:1014.

64 Owens DW, Jones SJ. The accident and emergency department management of deliberate self-poisoning. $\mathrm{Br} F$ Psychiatry 1988;152:830-3.

65 Blake DR, Bramble MG. Self-poisoning: psychiatric assessment by junior staff. BMF 1979;1:1763.

66 Blake DR, Mitchell JR. Self-poisoning: management of patients in Nottingham, 1976. BMf 1978;1:1032-5.

67 Linter C. Psychiatric involvement in case harm. British fournal of Social and Clinical Psychiatry 1985; $3: 11-5$

68 Hawton K, James R. General hospital services for attempted suicide patients: a survey in one Region. Health Trends $1995 ; 27: 18-21$

69 Ghodse AH. The attitudes of casualty staff and ambulance personnel towards patients who take drug overdoses. Soc Sci Med 1978;12:341-6.

70 Woodside $M$. Attempted suicides arriving at a general hospital. BMF 1958;i:411-4.

71 Patel A. Attitudes towards self-poisoning. BMF 1975;2:42630.

72 Barber J, Hodgkin G, Patel A, et al. Effect of teaching on students' attitudes to self-poisoning. BM7 1975;ii:431-4.

73 Ramon S, Bancroft J, Skrimshire A. Attitudes towards selfpoisoning among physicans and nurses in a general hospipoisoning among physicans and nurs

74 Creed F, Pfeffer J. Attitudes of house physicians towards self-poisoning patients. Medical Education 1981;15:340-5. 75 Brogan R, Ullyatt K, Pelosi A. Psychiatric services have limited role in deliberate self-poisoning. BMF 1998;317:416.

76 Platt S, Hawton K, Kreitman N, et al. Recent clinical and epidemiological trends in parasuicide in Edinburgh and Oxford: a tale of two cities. Psychol Med 1988;18:405-18.

77 Hall DJ. A psychiatric liaison service in a general hospital referrals and their appropriateness. Scottish Medical fournal 1994;39:141-4.

78 Yeo HM. The cost of treatment of deliberate self-harm. Arch Emerg Med 1993;9:8-14.

79 Butterworth E, O'Grady TJ. Trends in the assessment of cases of deliberate self-harm. Health Trends 1989;21:61.

80 Bagley C. The evaluation of a suicide prevention scheme by an ecological method. Social Science and Medicine 1968;2: $1-14$.

81 Jennings C, Barraclough B, Moss J. Have the Samaritans lowered the suicide rate? A controlled study. Psychol Med 1978;8:413-22.

82 Morgan H, Jones E, Owen J. Secondary prevention of nonfatal deliberate self-harm. The green card study. $\mathrm{Br} \mathcal{f}$ Psychiatry 1993;163:111-2.

83 Evans M, Morgan HG, Hayward A. A randomised controlled trial of the use of crisis telephone consultation for patients admitted after deliberate self harm. Br F Psychiatry (in press)

84 D'Zurilla TJ. Problem-solving therapy: a social competence approach to clinical intervention. New York: Springer, 1986.

85 Hawton K, McKeown S, Day A, et al. Evaluation of out-patient counselling compared with general practitione care following overdoses. Psychol Med 1987;17:751-61.

86 Gilbody S, House A, Owens D. The early repetition of deliberate self harm. $\mathcal{F} R$ Coll Physicians Lond 1997;31:1712.

87 Hes JP, Dor T. Suicide attempt and the emergency room of the general hospital. Ment Health Soc 1978;5:14-22.

88 Malone K, McCormack G, Malone JP. Non-fatal deliberate self-poisoning in Dublin's north inner city-an overview. Ir Med f 1992;85:132-5.
89 Hawton K, Marsack P, Fagg J. The attitudes of psychiatrists to deliberate self-poisoning: comparison with physicians and nurses. Br F Med Psychol 1981:54:341-8.

90 Jones DR. A follow-up of self-poisoned patients. $f \mathrm{R}$ Coll Gen Pract 1977;27:717-9.

91 Hawton K, Bancroft J, Catalan J, et al. Domiciliary and outpatient treatment of self-poisoning patients by medical and non-medical staff. Psychol Med 1981;11:169-77.

92 Van Heeringen C, Jannes S, Buylaert H, et al. The management of non-compliance with referral to out-patient after care among attempted suicide patients. Psychol Med 1995; 25:963-70.

93 Crockett AWB. Patterns of consultation and parasuicide. BMF 1987;295:476-8.

94 Turner RM. Parasuicide in an urban general practice 1970 1979. Fournal of the Royal College of General Practitioners 1982;32:273-81.

95 Petrie K. Recent general practice contacts of hospitalised suicide attempters. N Z Med f 1989;102:130-1.

96 Gardner R, Hanka R, O'Brien VC, et al. Psychological and social evaluation in cases of deliberate self-poisoning admitted to a general hospital. BMF 1977;2:1567-70.

97 Gorman D, Masterton G. General practice consultation patterns before and after intentional overdose: a matched control study. Br f Gen Pract 1990;40:102-5.

98 Turner RJ, Morgan HG. Patterns of health care in non-fatal deliberate self-harm. Psychol Med 1979;9:487-92.

99 Gibbons JS, Butler J, Urwin P, et al. Evaluation of a social work service for self-poisoning patients. $\mathrm{Br} \mathcal{F}$ Psychiatry 1978;133:111-8

100 Salkovskis PM, Atha C, Storer D. Cognitive-behavioural problem solving in the treatment of patients who repeatedly 1990;157:871-6.

101 McLeavey B, Daly R, Ludgate J, et al. Interpersonal problem-solving skills training in the treatment of selfpoisoning patients. Suicide Life Threat Behav 1994;24:38294.

102 Chowdhury N, Hicks RC, Kreitman N. Evaluation of an after-care service for parasuicide (attempted suicide) patients. Soc Psychiatry 1973;8:67-81.

103 Welu TC. A follow-up program for suicide attempters: evaluation of effectiveness. Suicide Life Threat Behav 1977; 7:17-20.

104 Allard R, Marshall M, Plante M. Intensive follow-up does not decrease the risk of repeat suicide attempts. Suicide Life Threat Behav 1992;22:303-14.

105 Van der Sande R, VanRooijen L, Buskens E, et al. Intensive in-patient treatment and community intervention versus routine care after attempted suicide. Br F Psychiatry 1997; 171:35-41.

106 Cotgrove A, Zirinsky L, Black D, et al. Secondary prevention of attemp

107 Linehan M, Armstrong H, Suarez A, et al. Cognitive behavioural treatment of chronically parasuicidal borderline patients. Arch Gen Psych 1991;48:1060-4.

108 Liberman RPE. Behaviour therapy vs insight-oriented therapy for repeated suicide attempters. Arch Gen Psych 1981;38:1126-30.

109 Torhorst A, Moller H, Burk F, et al. The psychiatric management of parasuicide patients: a controlled clinical study comparing different strategies of outpatient treatment. Crisis 1987;8:53-61.

10 Waterhouse J, Platt S. General hospital admission in the management of parasuicide: a randomised controlled trial. Br F Psychiatry 1990;156:236-42.

11 Montgomery S, Montgomery D, Jayanthi-Rani S, et al. Maintenance therapy in repeat suicidal behaviour: a placebo controlled trial. Ottawa: Proceedings of the Tenth International Congress for Suicide Prevention and Crisis Intervention, 1979 .

112 Hirsch SR, Walsh C, Draper R. Parasuicide: a review of treatment interventions. F Affect Disorders 1982;4:299-311.

113 Montgomery S, Roy D, Montgomery D. The prevention of recurrent suicidal acts. Br F Clin Pharmacol 1983;15:183-5.

114 Torhorst A, Moller H, Kurz A, et al. Comparing a three month and a twelve month outpatient aftercare programme for parasuicide repeaters. In: Moller HJ, Schmidtke A, Welz $\mathrm{R}$, editors. Current issues of suicidology. Berlin: SpringerVerlag, 1988:419-24. 